\title{
Malaria Vectors in the Municipality of Serra do Navio, State of Amapá, Amazon Region, Brazil
}

\author{
MM Póvoa/ ${ }^{+}$, RA Wirtz*, RNL Lacerda, MA Miles**, D Warhurst**
}

\begin{abstract}
Seção de Parasitologia, Instituto Evandro Chagas/Funasa, Av. Almirante Barroso 492, 66090-000 Belém, PA, Brasil *Walter Reed Army Institute of Research, Washington, DC, USA **Pathogen Molecular Biology and Biochemistry Unit, Department of Infectious and Tropical Diseases, London School of Hygiene and Tropical

Medicine, London, UK
\end{abstract}

We conducted a survey to determine the vectors of malaria in six localities of Serra do Navio municipality, State of Amapá, from 1990 to 1991. Malaria infection rates of 29.3\%, 6.2\% and 20.4\% were detected by human blood smears in Colônia Água Branca, Porto Terezinha and Arrependido, respectively. There was no malaria infection detected in Serra do Navio. Fifteen species were identified among 3,053 anopheline mosquitoes collected by human bait and 64.4\% were identified as Anopheles albitarsis s.l., 16.7\% An. braziliensis, 9.5\% An. nuneztovari and 5.8\% An. triannulatus. An. darlingi, the main vector of malaria in the Amazon region of Brazil, was scare. Using enzyme-linked immunosorbent assay (ELISA), a total positive rate of 0.8\% (23/2876) was found for six species: fifteen An. albitarsis s.l., four An. nuneztovari, and one of each: An. braziliensis, An. triannulatus, An. oswaldoi and An. rangeli. Nine of 23 positive mosquitoes were infected with Plasmodium malariae, eight with $\mathrm{P}$. vivax VK210, three with P. vivax VK247 and three with P. falciparum. Since An. albitarsis s.l. was collected feeding on humans, was present in the highest density and was positive by ELISA for malaria sporozoites, it probably plays an important role in malaria transmission in this area.

Key words: mosquito - Anopheles - malaria vector - Plasmodium - Brazil

Since the 80 's, several studies on malaria transmission have been carried out in different parts of the Brazilian Amazon and, based on dissections, enzyme-linked immunosorbent assays (ELISA) and anthropophilic behavior, Anopheles darlingi Root, 1926 was found to be the main vector. Other species such as An. albitarsis s.l. LynchArribalzaga, 1878, An. deaneorum Rosa-Freitas, 1989, An. oswaldoi (Peryassú, 1922), An. mediopunctatus s.l. Theobald, 1903 (now a complex of three species - Sallum et al. 1999) and An. triannulatus (Neiva and Pinto, 1922) are considered to be potentially regional vectors (Arruda et al. 1986, Tadei et al. 1988, Deane 1988, Lourenço-

This study received financial support from the UNDP/ World Bank Special Programme for Research and Training in Tropical Disease (grant ID 870284) and from the Instituto Evandro Chagas/Funasa, Ministry of Health, Brazil.

Corresponding author. Fax: +55-91-211.4417. E-mail: pepovoa@amazon.com.br

*Present address: Division of Parasitic Diseases, CDC, 4770 Buford Highway, NE Atlanta GA 30341-3724, USA

Received 15 May 2000

Accepted 27 September 2000
de-Oliveira et al. 1989, Klein et al. 1991, Branquinho et al. 1996) and, more recently, An. marajoara Galvão and Damasceno, 1942 has been determined to be a new emerging malaria vector near Macapá, State of Amapá (Segura 1998). Despite the high prevalence and wide distribution of human malaria in Brazil, there are areas or states such as Amapá where little information about abundance and identification of anopheline mosquitoes, or their vector status is available.

The present study was conducted to identify anopheline mosquitoes and to determine their role as potential vectors in each of six localities in the Serra do Navio (SNV) municipality, in Amapá.

\section{MATERIALS AND METHODS}

Study site - The study area is the municipality of SNV (0 $57^{\circ} 00^{\prime \prime}$ S, 52 $2^{\circ} 00^{\prime} 49^{\prime \prime} \mathrm{W}$; elevation 380 $\mathrm{m})$ located $146 \mathrm{~km}$ north of Macapá, the capital of Amapá. The climate is that of a tropical rainforest with a rainy season in which $85 \%$ of the precipitation generally occurs, and a dry season. From December to March it rains several times every day with high intensity but short duration; from April to June the rain is continuous and heavy; and from July to November (the dry season) the rain is less frequent and of lower intensity. The mean rainfall for 1990 was $293.6 \mathrm{~mm}$ (January-June) and 129.1 mm (July-December). 
SNV was created in 1947, when Icomi (Indústria e Comércio SA) received a license to explore mineral resources in this area for a period of 50 years (Gusmão 1991). From 1954 to 1960, the company constructed an industrial park and a residential village to accommodate a population of about 2,000-2,500 inhabitants. The administrative, industrial and residential areas (SNV treated area) were completely isolated from one another. Facilities included a water purification plant, a sewage treatment plant, rain water drainage, a rubbish incinerator and a hospital. A disease control program was initiated, aimed mainly at malaria and leishmaniasis, that consisted of water purification, houses with window and door screening, biannual residual insecticide (DDT) spraying, domestic animal control and administration of chloroquinised salt to every inhabitant. The three localities (CAB: Colônia Água Branca, PT: Porto Terezinha, and ARR: Arrependido) are small villages which have a standard of living in marked contrast with that of the population of SNV (the treated area). The houses in these villages are made of wood with roofs of zinc panels, strong plastic or dry palm leaves, and there has been no vector control to reduce parasite transmission.

Mosquito collection - Anopheline mosquito collections were carried out four times, twice in each year, for about 20 days during each of the wet and dry seasons. Different collection sites were chosen within each locality. These included SNV (the treated area), SNV the forest, and SNV Carpintaria, as well as CAB, PT and ARR. Carpintaria was separated from SNV because, although people from SNV work there during the day, no one stays there at the time of peak biting activity of anophelines. The forested area was part of SNV, located between SNV and CAB, PT and ARR. It was not treated. Each sampling site was visited for at least three days during each trip, by a protozoologist and three entomological technicians. Human bait catches were made peridomestically (indoors and outdoors) in the residential areas and light traps (Shannon and CDC) were used in the forest. Collection periods were 18-22 $\mathrm{h}$ and in addition, at least one $12 \mathrm{~h}$ collection was conducted in each locality. Mosquitoes were collected by pairs of collectors and a rotating catch timetable was used to prevent a bias due to personal differences in attraction and skill. The mosquitoes were separated at the time of collection into glass tubes. The identification of adult anophelines was carried out using taxonomic keys (Forattini 1962, Faran \& Linthicum 1981).

Detection of sporozoites - All anophelines from light traps and human bait captures were tested for the Plasmodium circumsporozoite protein (CSP) by ELISA (Wirtz et al. 1987). Specimens were identified, placed in capped vials and kept in plastic bags containing silica gel. In the laboratory at Evandro Chagas Institute, Belém, specimens were stored at $-20^{\circ} \mathrm{C}$ until tested. The head and thorax of each specimen was triturated prior to use in the test. Positive controls for each Plasmodium species were placed in two wells of each test plate. Negative controls (uninfected mosquito homogenates) were placed in four wells and blocking buffer in four wells. The same batches of capture monoclonals, peroxidase-labelled mono-clonals and positive controls were used in all tests. Positivity was determined by both visual reading and at 405-414 $\mathrm{nm}$ using an ELISA reader $30 \mathrm{~min}$ after the substrate had been added. The cut-off was selected as twice the mean of negative controls (Wirtz et al. 1987).

\section{RESULTS}

Collection parameters - Ninety-five mosquito collections were made during four trips (two each in the dry and rainy seasons). The usual capture time was $4 \mathrm{~h}$ a day (from 18 to $22 \mathrm{~h}$ ) based on the peak activity of the species in all localities as determined by the $12 \mathrm{~h}$ collections. The range of temperature during collections was $23^{\circ} \mathrm{C}$ to $31^{\circ} \mathrm{C}$ for both wet and dry seasons and the relative humidity ranged from 78 to $100 \%$ in the wet season and from 62 to $100 \%$ in the dry season with means of $96 \%$ and $80.3 \%$, respectively. Collections were carried out during all four phases of the moon, on days with or without rain and wind. The number of bites/man/hour for each area during dry and rainy seasons is shown in Table I, with the highest index obtained in the dry season.

Distribution of mosquito species - Fifteen anopheline species were identified among 3,053 mosquitoes collected in the four localities. The most frequent species and their distribution by locality and season are shown in Table II. The majority (96.4\%) of mosquitoes caught consisted of four species, An. albitarsis s.l. (64.4\%), An. braziliensis (Chagas, 1907) (16.7\%), An. nuneztovari Galbadon, 1940 (9.5\%) and An. triannulatus (5.8\%). The remaining 11 species [An. oswaldoi, An. darlingi, An. peryassui Dyar and Knab, 1908, An. minor Costa Lima, 1929, An. neivai Howard, Dyar and Knab, 1903, An. intermedius (Chagas, 1908), An. mediopunctatus s.l., An. rangeli Galbadon, CovaGarcia \& Lopes, 1940, An. evansae (Berthes, 1926), An. argyritarsis Robineau-Desvoidy, 1827 and Chagasia bonneae Root, 1927] were uncommon (3.6\%). Most mosquitoes (77.2\%) were collected during the dry season.

Sporozoite rate by salivary gland dissection We carried out 88 dissections of mosquitoes col- 
TABLE I

Number of bites/man/hour for all areas in which anophelines were collected, during the dry and rainy seasons (February and August 1990 and April and September 1991)

\begin{tabular}{lcc}
\hline Study area & Dry season & Rainy season \\
\hline Serra do Navio (SNV)-treated area & 0 & 0 \\
Serra do Navio forest & 1.1 & 1.4 \\
Serra do Navio Carpintaria & $c$ & 4.4 \\
Colonia Água Branca & $6.5^{a}$ & 2.5 \\
Porto Terezinha & 2.4 & 1.1 \\
Arrependido & 4.7 & $6.6^{b}$ \\
\hline
\end{tabular}

$a$ : $\mathrm{P}>0.05$, Chi-square test; $b$ : $\mathrm{P}<0.05$, Chi-square test; $c$ : locality $3 \mathrm{~km}$ from SNV (the treated area), at the foot of the hill

TABLE II

Number of each Anopheles species collected during 1990-1991 in study areas Serra do Navio (SNV), Colonia Água Branca (CAB), Porto Terezinha (PT) and Arrependido (ARR), by season

\begin{tabular}{|c|c|c|c|c|c|c|}
\hline Anopheles species & $\begin{array}{l}\mathrm{SNV}^{a} \\
\mathrm{~W} / \mathrm{D}\end{array}$ & $\begin{array}{l}\text { CAB } \\
\text { W/D }\end{array}$ & $\begin{array}{c}\mathrm{PT} \\
\text { W/D }\end{array}$ & $\begin{array}{l}\text { ARR } \\
\text { W/D }\end{array}$ & $\begin{array}{l}\text { Total } \\
\text { W/D }\end{array}$ & $\begin{array}{c}\text { Grand } \\
\text { Total }\end{array}$ \\
\hline An. albitarsis s.l. & $\begin{array}{l}91 / 91 \\
(43.7)\end{array}$ & $\begin{array}{l}1 / 14 \\
(7.0)\end{array}$ & $\begin{array}{l}71 / 90 \\
(48.6)\end{array}$ & $\begin{array}{c}200 / 1407 \\
(76.8)\end{array}$ & $363 / 1602$ & $\begin{array}{l}1965 \\
(64.4)\end{array}$ \\
\hline An. braziliensis & $\begin{array}{l}30 / 27 \\
(13.7)\end{array}$ & $\begin{array}{c}1 / 0 \\
(0.5)\end{array}$ & $\begin{array}{l}33 / 37 \\
(21.1)\end{array}$ & $\begin{array}{c}35 / 348 \\
(18.3)\end{array}$ & $99 / 412$ & $\begin{array}{c}511 \\
(16.7)\end{array}$ \\
\hline An. nuneztovari & $\begin{array}{c}8 / 41 \\
(11.8)\end{array}$ & $\begin{array}{l}61 / 70 \\
(65.1)\end{array}$ & $\begin{array}{l}14 / 31 \\
(13.5)\end{array}$ & $\begin{array}{l}6 / 50 \\
(2.7)\end{array}$ & $89 / 201$ & $\begin{array}{l}290 \\
(9.5)\end{array}$ \\
\hline An. triannulatus & $\begin{array}{l}88 / 16 \\
(25.0)\end{array}$ & $\begin{array}{c}7 / 20 \\
(12.5)\end{array}$ & $\begin{array}{l}21 / 16 \\
(11.1)\end{array}$ & $\begin{array}{c}7 / 2 \\
(0.5)\end{array}$ & $123 / 54$ & $\begin{array}{l}177 \\
(5.8)\end{array}$ \\
\hline An. oswaldoi & $\begin{array}{l}4 / 10 \\
(3.4)\end{array}$ & $\begin{array}{c}5 / 17 \\
(10.2)\end{array}$ & $\begin{array}{c}2 / 1 \\
(0.9)\end{array}$ & $\begin{array}{c}6 / 0 \\
(0.3)\end{array}$ & $17 / 28$ & $\begin{array}{c}45 \\
(1.5)\end{array}$ \\
\hline An. darlingi & $\begin{array}{c}0 / 6 \\
(1.4)\end{array}$ & $\begin{array}{c}0 / 4 \\
(1.8)\end{array}$ & $\begin{array}{c}1 / 1 \\
(0.6)\end{array}$ & $\begin{array}{c}0 / 4 \\
(0.2)\end{array}$ & $1 / 15$ & $\begin{array}{c}16 \\
(0.5)\end{array}$ \\
\hline An. peryassui & $\begin{array}{c}0 / 1 \\
(0.2)\end{array}$ & $\begin{array}{c}0 / 3 \\
(1.4)\end{array}$ & $\begin{array}{c}1 / 1 \\
(0.6)\end{array}$ & $\begin{array}{c}0 / 4 \\
(0.2)\end{array}$ & $1 / 9$ & $\begin{array}{c}10 \\
(0.3)\end{array}$ \\
\hline An. minor & $0 / 0$ & $\begin{array}{c}0 / 1 \\
(0.5)\end{array}$ & $\begin{array}{c}0 / 8 \\
(2.4)\end{array}$ & $\begin{array}{c}0 / 1 \\
(<0.1)\end{array}$ & $0 / 10$ & $\begin{array}{c}10 \\
(0.3)\end{array}$ \\
\hline Other species ${ }^{b}$ & $\begin{array}{c}0 / 3 \\
(0.7) \\
\end{array}$ & $\begin{array}{c}0 / 2 \\
(1.0) \\
\end{array}$ & $\begin{array}{c}0 / 5 \\
(1.5) \\
\end{array}$ & $\begin{array}{l}4 / 15 \\
(0.9) \\
\end{array}$ & $4 / 25$ & $\begin{array}{c}29 \\
(0.9) \\
\end{array}$ \\
\hline Total & $221 / 195$ & $75 / 140$ & $142 / 189$ & $259 / 1832$ & $697 / 2356$ & 3053 \\
\hline
\end{tabular}

$a$ : consists of mosquitoes collected in the forest and Carpintaria (none was collected in the treated area); $b$ : other Anopheles mosquitoes collected in low numbers included: An. intermedius, An. mediopunctatus, An. rangeli, An. evansae, An. neivai, An. argyritarsis and Chagasia bonneae; W: wet season; D: dry season; ( ): percentages determined in relation to the total number of mosquitoes collected by locality.

lected from human bait, of four species: $35 A n$. albitarsis s.l., 20 An. braziliensis, 15 An. nuneztovari, $10 \mathrm{An}$. triannulatus and 8 An. oswaldoi, of which $46(52.2 \%)$ mosquitoes were parous. Of those, three had sporozoites in the salivary glands (one each of An. albitarsis s.l., An. braziliensis and An. nuneztovari) and four had oocysts on the stomach wall (two were the same specimens that had sporozoites - An. braziliensis and An. nuneztovari - and two An. oswaldoi). The overall infection rate for the salivary glands was $3.4 \%$ and for stomachs $4.5 \%$.
Infection with malaria parasites - The positive rate of the total number of mosquitoes tested by ELISA performed with CSP antigen for $P$. falciparum, $P$. vivax VK210, $P$. vivax VK247 and $P$. malariae, was $0.8(23 / 2876)$ belonging to six mosquito species: 15 An. albitarsis s.l., four An. nuneztovari and one of each: An. braziliensis, An. triannulatus, An. oswaldoi and An. rangeli. Nine were positive for P. malariae (five An. albitarsis s.l., and one of each An. braziliensis, An. nuneztovari, An. triannulatus and An. rangeli), eight for P. vivax VK210 (seven An. albitarsis s.l. 
and one An. nuneztovari), three for P. falciparum (two An. albitarsis s.l. and one An. oswaldoi) and three for P. vivax VK 247 (one An. albitarsis s.l. and two An. nuneztovari) as shown in Table III. Abdomens of all positive specimens were also retested by ELISA and only the An. triannulatus was negative for this second test.

No mosquitoes were collected in the residential and administrative part of the treated area (SNV).

P. malariae, found in some mosquitoes collected in the SNV-forest, could be P. brasilianum Gonder and Berenberg-Gossler, 1908 which is a monkey parasite (Deane 1992) that are indistinguishable by morphological techniques from $P$. malariae (Lal et al. 1988) and had already been detected in monkeys captured in these localities (Deane 1969, Deane \& Ferreira Neto 1969, Deane et al. 1971).

\section{DISCUSSION}

Migratory movement has played an important role in the spread of malaria in Brazil (Marques 1986), since the exodus in Brazil has been from town to rural areas and within the rural areas in the Amazon region. This was initially a result of a Federal government program for populating and developing the Amazon region based on a belief that in the Amazon region everyone was entitled to land in order to facilitate economic development. This resulted in a major migration of people from all parts of Brazil to become farmers, goldminers or hydroelectric workers (Alecrim 1992). Deforestation and burning were carried out to provide space for settlements, resulting in drastic changes in the ecology of this region (Marques 1987). Those changes and the growth of settlements without provision for infrastructure, are thought to have contributed to the spread of malaria throughout the Amazon region by the formation of new breeding sites for Anopheles mosquitoes (Marques 1986).

In the 60's, companies such as Icomi established projects which created new residential localities and new jobs and this subsequently increased migration. Even companies that had made extensive preparations faced problems of morbidity and mortality from tropical diseases, mainly malaria and leishmaniasis. This was the stimulus for Icomi to establish a program for the control of malaria, the most important disease in the area (Gusmão 1991).

The prevalence of malaria infections in the localities (CAB, PT and ARR) during the period of this study (1990-1991) was $29.3 \%, 6.2 \%$ and $20.4 \%$, respectively, and there were no malaria infections in SNV-treated area (Póvoa 1993). Data

\section{TABLE III}

Positive rate by enzyme-linked immunosorbent assay of Anopheles species collected in the localities [Serra do Navio $^{a}$ (SNV), Colonia Água Branca (CAB), Porto Terezinha (PT) and Arrependido (ARR)]

\begin{tabular}{|c|c|c|c|c|c|c|c|c|c|c|c|c|c|c|c|c|c|}
\hline \multirow{2}{*}{$\begin{array}{l}\text { Anopheles } \\
\text { species }^{b}\end{array}$} & \multicolumn{4}{|c|}{ PF } & \multicolumn{4}{|c|}{ PV1 } & \multicolumn{5}{|c|}{ PV2 } & \multicolumn{2}{|c|}{ PM } & \multicolumn{2}{|r|}{ TIM/TTM } \\
\hline & SNV & $\mathrm{CAB}$ & PT & ARR & SNV & $\mathrm{CAB}$ & PT & ARR & SNV & $\mathrm{CAB}$ & PT & ARR & SNV & $\mathrm{CAB}$ & PT & ARR & $(\%)$ \\
\hline An.albitarsis s.l & - & - & - & 2 & - & - & - & $7^{c}$ & - & - & - & 1 & 3 & - & - & 2 & $\begin{array}{c}15 / 1833 \\
(0.82)\end{array}$ \\
\hline An. brazileinsis & - & - & - & - & - & - & - & - & - & - & - & - & - & - & - & $1^{c}$ & $\begin{array}{l}1 / 480 \\
(0.20)\end{array}$ \\
\hline An. nuneztovari & - & - & - & - & - & 1 & - & - & - & $2^{c}$ & - & - & - & 1 & - & - & $\begin{array}{l}4 / 280 \\
(1.40)\end{array}$ \\
\hline An. triannulatus & - & - & - & - & - & - & - & - & - & - & - & - & 1 & - & - & - & $\begin{array}{l}1 / 177 \\
(0.56)\end{array}$ \\
\hline An. oswaldoi & - & - & - & 1 & - & - & - & - & - & - & - & - & - & - & - & - & $\begin{array}{c}1 / 45 \\
(2.22)\end{array}$ \\
\hline Other species ${ }^{d}$ & - & - & - & - & - & - & - & - & - & - & - & - & $1^{e}$ & - & - & - & $\begin{array}{c}1 / 28 \\
(3.57)\end{array}$ \\
\hline Total & - & - & - & 3 & - & 1 & - & 7 & - & 2 & - & 1 & 5 & 1 & - & 3 & $\begin{array}{r}23 / 2876 \\
(0.80)\end{array}$ \\
\hline
\end{tabular}

$a$ : consists of mosquitoes collected in the forest and in Carpintaria; $b$ : An. darlingi, An. peryassui and An. minor were all negative; $c$ : one of each of these mosquitoes was also positive by dissection (sporozoite); $d$ : other Anopheles mosquitoes collected in low number included: An. intermedius, An. mediopunctatus, An. rangeli, An. evansae, An. argyritarsis and Chagasia bonneae; $e$ : An. rangeli; $f$ : total tested including negative specimens; PF: Plasmodium falciparum; PV1: P. vivax VK210; PV2: P. vivaxVK247; PM: P. malariae; TIM: total of infected mosquitoes; TTM: total of tested mosquitoes; -: negative; $($ ): percentages determined in relation to infected mosquito by the total number of collected mosquito. 
from 1961 (prior to the control measures) show malaria infection in SNV (47.1\%), then a sharp decrease in the rate to $4.3 \%$ immediately after the establishment of the daily intake of chloroquinised salt in 1963 as part of the malaria control program established by Icomi until 1993. Therefore, in the treated area at SNV, it was not surprising to find no evidence of malaria infection.

Unpublished records of the Anopheles species distribution in the SNV area obtained by Icomi malaria control program, show that in the 60's $A n$. darlingi was found close to the SNV residential areas. After the implementation of their control program, this species disappeared from $\mathrm{SNV}$ as confirmed by Deane and Ferreira Neto (1969), and has only been occasionally reported from SNV Carpintaria (the present study).

Our findings support the Icomi data since we collected An. darlingi $(\mathrm{n}=16)$ from all localities except SNV (the treated area). In the forest connecting SNV residential and administrative areas to the other three localities, the Anopheles species collected during our study are those considered predominantly zoophilic (e.g. An. triannulatus, An. rangeli and $A n$. evansae) (Consoli \& Oliveira 1994).

Our results demonstrate that the number of bites/man/hour is significantly higher at SNVCarpintaria during the dry season, possibly supporting the observation that most malaria transmission in the Amazon Basin occurs at this time (Deane 1988). However, in all other localities, no seasonal differentiation was observed. The locality ARR had significantly higher (Chi-square test, $\mathrm{P}<0.05$ ) bites/man/hour in both seasons compared with all other localities except Carpintaria and also a high malaria infection rate (20.4\%). Because 14/23 of the mosquitoes positive by ELISA were collected at ARR, and only $4 / 23$ at CAB (in spite of a malaria infection rate of $29.3 \%$ ), we suggest that the highest risk for malaria transmission was for the inhabitants of ARR.

Reports on malaria vectors in Brazil are few. Based on studies carried out in the 40's and 50's, it was established that along the coast, malaria was transmitted with a low level of endemicity by the brackish-water breeder An. aquasalis and in all other areas where malaria transmission occurred, $A n$. darlingi was the primary vector. However, species of the subgenus Kerteszia were also important on the transmission of malaria in the southern part of Brazil. Other species such as $A n$. albitarsis and An. braziliensis were sometimes of secondary importance as malaria vectors (Deane et al. 1946, 1948). In our study we determined species carrying human malaria sporozoites detectable by ELISA, were the same as those reported in past studies in Brazil (Arruda et al. 1986, Tadei et al. 1988, Lourenço-de-Oliveira et al. 1989, Branquinho et al. 1996), plus An. braziliensis and $A n$. rangeli. The latter was positive only for $P$. malariae/brasilianum, but we do not believe that this specie take role on the transmission of both, human and simian malaria in the Brazilian Amazon.

Because An. albitarsis s.l. was caught with human bait, presented the highest density over localities, was positive by ELISA for the four tested species of Plasmodium and positive by salivary glands dissection for malaria sporozoites, it probably plays an important role in the epidemiology of malaria in these localities. It is also worth noting the number of An. nuneztovari caught in $\mathrm{CAB}$, which, as in Venezuela (Gabaldón 1981, RubioPalis \& Curtis 1992) and in Suriname (Rozendal 1990), probably plays a role in local malaria transmission.

All Anopheles mosquitoes positive for $P$. malariae were collected in the forest area, where on several occasions during the catches we saw small monkeys. Since $P$. brasilianum (monkey malaria parasite) is genetically and morphologically indistinguishable from $P$. malariae (Lal et al. 1988), probably a sylvatic cycle of this parasite occurs in this area. Our records did not show infection in man caused by $P$. malariae and the SNV hospital and Fundação Nacional de Saúde records show a very low prevalence of this parasite, yet a high positivity in mosquitoes was detected for $P$. malariae in SNV. The maintenance of this Plasmodium could therefore be through the monkeys.

Marques $(1986,1987)$ showed that the spread of malaria in Brazil started in the 60's with the building of new roads followed in the 70's with the establishment of hydroelectric projects and in 80 's with the emergence of the gold prospecting sites. He classified transmission areas of malaria in Brazil as "stable malaria" (old transmission areas) and "frontier malaria" (recent transmission areas). The Meeting of World Health Organization (WHO) held in Amsterdam, in 1992, resulted in a global malaria control strategy which suggested that each country, based on its specific characteristics of malaria transmission, had to identify local problems and priorities in order to apply appropriate interventions (WHO 1992). Based on the WHO suggestions and considering the classification made by Marques, our localities, CAB, PT and ARR have the characteristics of areas of "stable malaria".

The control measures used at SNV aimed at decreasing the human/vector contact were very effective (i.e., we collected very few mosquitoes and they were primarily zoophilic, and no malaria cases were detected by blood smears). In contrast, 
after the desativation of the control system at SNV, human malaria cases were registered and we collected infected mosquitoes within the residences. Similar institutional programs are likely to dramatically reduce malaria transmission in the Amazon region of Brazil.

\section{ACKNOWLEDGMENTS}

To assistance in field work by Raimundo Nivaldo de Almeida and Orlando Vaz, the Icomi hospital technical personnel and the logistic support of Icomi. To Jan Conn, Richard Wilkerson and Yasmin Rubio for commenting on the manuscript.

\section{REFERENCES}

Alecrim W 1992. Malaria, prospecting activities and government policies in the Amazon region. Rev Inst Med Trop São Paulo 34: 48.

Arruda M de, Carvalho MB, Nussenweig RS, Maracic M, Ferreira AW, Cochrane AH 1986. Potential vectors of malaria and their different susceptibility to Plasmodium falciparum and Plasmodium vivax in northern Brazil identified by immunoassay. Am J Trop Med Hyg 35: 873-881.

Branquinho MS, Araújo MS, Natal D, Marelli MT, Rocha RM, Taveira FAL, Kloetzel JK 1996. Anopheles oswaldoi an important potential malaria vector in Acre, Brazil. Trans R Soc Trop Med Hyg 90: 233.

Consoli RA, Oliveira RL 1994. Classificação das principais espécies de mosquitos de importância sanitária. In Principais Espécies de Mosquitos de Importância Sanitária, Fiocruz, Rio de Janeiro, p. 17-92.

Deane LM 1969. Plasmodia of monkeys and malaria eradication in Brazil. Rev Latino Micro Parasit 11: 69-73.

Deane LM 1988. Malaria studies and control in Brazil. Am J Trop Med Hyg 38: 223-230.

Deane LM 1992. Simian malaria in Brazil. Mem Inst Oswaldo Cruz 87(Suppl. III): 1-20.

Deane LM, Ferreira Neto JA 1969. Encontro do Plasmodium brasilianum em macacos do Território Federal do Amapá, Brasil. Rev Inst Med Trop São Paulo 11: 199-202.

Deane LM, Causey OR, Deane MP 1946. An illustrated key by adult female characteristics for identification of thirty-five species of Anophelini from Northeast and Amazon regions of Brazil, with note on the malaria vectors (Diptera: Culicidae). Am J Trop Med Hyg 18: 1-18.

Deane LM, Causey OR, Deane MP 1948. Notas sobre a distribuição e a biologia dos anofelinos das regiões Nordestina e Amazônica do Brasil. Rev Ser Esp Saúde Publ 1: 827-965.

Deane LM, Deane MP, Ferreira Neto JA, Almeida FB 1971. On the transmission of simian malaria in Brazil. Rev Inst Med Trop São Paulo 13: 311-319.

Faran ME, Linthicum KJ 1981. A handbook of the Amazonian species of Anopheles (Nyssorhynchus) (Diptera: Culicidae). Mosq Syst 13: 1-81.

Forattini OP 1962. Tribo Anophelini. In OP Forattini, Entomologia Médica, Faculdade de Higiene e Saúde
Pública, Universidade de São Paulo, São Paulo, p. 303-503.

Gabaldón A 1981. Anopheles nuñez-tovari: importante vector y agente de malaria refractaria en Venezuela. Bol Dir Malaria San Amb 21: 28-38.

Gusmão HH 1991. Programa de Saúde Integrado ao Complexo da Infra-estrutura Social: 25 Anos na Amazônia: 1961-1985. Faculdade de Saúde Pública/ USP, São Paulo, 75 pp.

Klein TA, Lima JBP, Tada MS, Miller R 1991. Comparative susceptibility of anopheline mosquitoes in Rondônia, Brazil to infection by Plasmodium falciparum. J Am Mosquito Control Assoc 6: 700707.

Lal AA, de La Cruz VF, Collins WE, Campbell GH, Porcell, PM, McCutchan TF 1988. Circumsporozoite protein gene from Plasmodium brasilianum. J Biol Chem 263: 5595-5598.

Lourenço-de-Oliveira R, Guimarães AEG, Monique A, Silva TF, Castro MG, Motta M A, Deane LM 1989. Anopheline species, some of their habits and relation to malaria endemic areas of Rondônia State, Amazon Region of Brazil. Mem Inst Osw Cruz 84: 501-514.

Marques AC 1986. Um estudo sobre a dispersão de casos de malária no Brasil. Rev Bras Mal Doenças Trop 38: 51-75.

Marques AC 1987. Human migration and the spread of malaria in Brazil. Parasitol Today 3: 166-170.

Póvoa MM 1993. Studies on Malaria in Serra do Navio Region, Amapá State, Brazil, PhD Thesis, University of London, London, UK, 259 pp.

Rozendal JA 1990. Epidemiology and Control of Malaria in Suriname, with Special Reference to Anopheles darlingi, ICG Printing b.v., Dordrecht, 171 pp.

Rubio-Palis Y, Curtis CF 1992. Biting and resting behavior of anophelines in western Venezuela and implications for control of malaria transmission. Med Vet Entomol 6: 325-334.

Sallum MAM, Wilkerson RC, Forattini OP 1999. Taxonomic study of species formerly identified as Anopheles mediopunctatus and resurrection of An. costai (Diptera: Culicidae). J Med Entomol 36: 282-300.

Segura MNO 1998. Estudo do Anopheles (Nys) darlingi Root 1926 e Anopheles (Nys) albitarsis Arribalzaga 1878 (Diptera: Culicidae) como Vetores de Malária numa Mesma Área de Transmissão, e Caracterização de Espécies do Complexo albitarsis, MSc Thesis, Universidade Federal do Pará, Belém, 128 pp.

Tadei WP, Santos JMM, Costa WLS, Scarpassa VM 1988. Biologia de anofelinos amazônicos. XII Ocorrência de espécies de Anopheles, dinâmica de transmissão e controle da malária na zona urbana de Ariquemes (Rondônia). Rev Inst Med Trop São Paulo 30: 221-251.

Wirtz RA, Burkor TR, Graves PM 1987. Field evaluation of enzyme-linked immunosorbent assays for Plasmodium falciparum and Plasmodium vivax sporozoites in mosquitoes (Diptera: Culicidae) from Papua New Guinea. J Med Entomol 24: 433-437.

WHO-World Health Organization 1992. World Malaria situation in 1990. Bull WHO 70: 801-807. 